\section{Random Primed Gene Walking PCR: A Simple Procedure to Retrieve Nucleotide Fragments Adjacent to Known DNA Sequences}

BioTechniques 21:20 (July 1996)

The development of the polymerase chain reaction (PCR) has simplified the cloning and studying of nucleotide sequences. Modifications of PCR protocols have been used for gene walking. Most of these protocols, such as inverse PCR (5), require multiple steps. Recently, a few variations of a procedure called targeted gene walking PCR (TGW-PCR) have been described to accomplish the same task (1-3). However, in most cases, TGW-PCR amplifies multiple nonspecific PCR products from which gene-specific PCR products must be distinguished and purified before attempting to sequence them (1-3).

We have developed a technique that eliminates the amplification of multiple spurious products and therefore the need for band purifications. Our technique enriches single-stranded (ss) DNA sequences either upstream or downstream from the known sequences followed by a random amplification.

ssDNA was obtained by using hightemperature annealing of a primer to the known DNA sequence. In developing this technique, we used primers that annealed to different fragments of a Borrelia burgdorferi cheA homolog gene. The PCR used $0.5 \mu \mathrm{g}$ of borrelial DNA and 100 pmol of specific primer in $100 \mu \mathrm{L}$ reaction mixture and consisted of 40 cycles $\left(94^{\circ} \mathrm{C}\right.$ for $1 \mathrm{~min} ; 55^{\circ} \mathrm{C}$ for $1 \mathrm{~min}$; and $72^{\circ} \mathrm{C}$ for $1 \mathrm{~min}$ ). For reaction $\mathrm{A}$, the specific primer was UP3 (5'-CAGCCTCACTGACAAGAT$\left.3^{\prime}\right)$, and for reaction $\mathrm{B}$, the specific primer was UP6 (5'-CCTCAAGATCTGATTCTG-3'). The absence of doublestranded (ds) DNA products after the first set of amplifications was verified by agarose gel electrophoresis (data not shown).

ssDNA $(10 \mu \mathrm{L}$ of the first PCR mixture) was then used in a second PCR mixture $(100 \mu \mathrm{L})$ containing the same specific primer and a 10-mer (5'-CAAGGGCTCA-3') nonspecific primer, both at 100 pmol. The second PCR consisted of 40 cycles $\left(94^{\circ} \mathrm{C}\right.$ for $1 \mathrm{~min}$; $40^{\circ} \mathrm{C}$ for $1 \mathrm{~min}$; and $72^{\circ} \mathrm{C}$ for $1 \mathrm{~min}$ ). The temperature for the first PCR was determined by trial/failure and that of the second one was determined by the melting point of the specific primer.

By using this technique, 1-3 bands were obtained per reaction, and nearly all the bands appeared to be specific gene sequences as assessed by Southern blot analysis using digoxigeninlabeled internal nucleotide sequences (Genius ${ }^{\mathrm{TM}}$ system; Boehringer Mannheim, Indianapolis, IN, USA) as probes (Figure 1). Three PCR products $(0.5$ and $0.3 \mathrm{~kb}$ from reaction $\mathrm{A}$ and $0.8 \mathrm{~kb}$ from reaction $\mathrm{B}$ ) were ligated into plasmid $\mathrm{pCR}^{\mathrm{TM}}$ II (TA plasmid; Invitrogen, San Diego, CA, USA) and were subjected to nucleotide sequencing (4).

The three inserts contained nucleotide sequences corresponding to the $B$. burgdorferi cheA homolog gene. Random primed gene walking PCR amplified multiple specific bands with virtually no spurious products. Therefore,

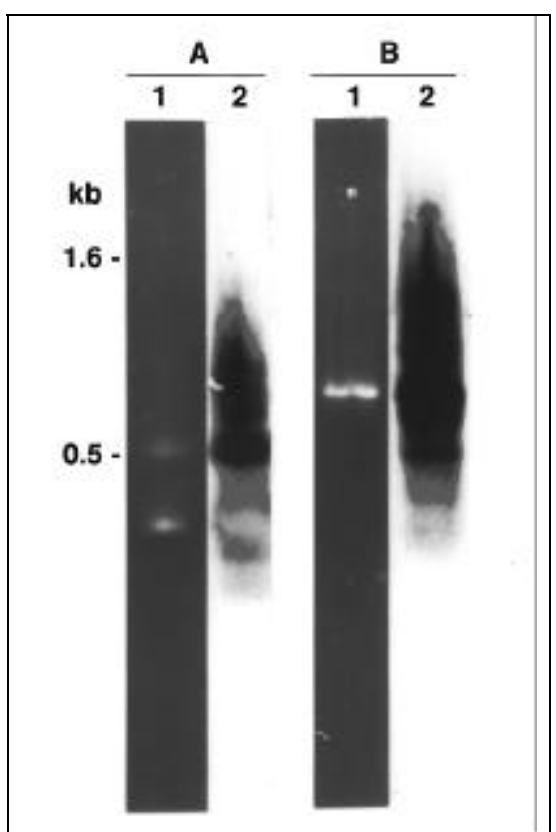

Figure 1. Random primed gene walking PCR of B. burgdorferi DNA. A) Amplification products obtained by using primer UP3. B) Amplification products obtained by using primer UP6. For both $\mathrm{A}$ and $\mathrm{B}$, agarose gel stained with ethidium bromide (lane 1) and Southern blot analysis using internal sequence probes (lane 2). this technique may allow direct sequencing of unknown DNA sequences without the need for DNA cloning.

\section{REFERENCES}

1.Dominguez, O. and C. Lopez-Larrea. 1994. Gene walking by unpredictably primed PCR. Nucleic Acids Res. 22:3247-3248.

2.Malo, M.S., K. Srivastava, J.M. Andresen, X.N. Chen, J.R. Korenberg and V.M. Ingram. 1994. Targeted gene walking by low stringency polymerase chain reaction: assignment of a putative human brain sodium channel gene (SCN3A) to chromosome 2q24-31. Proc. Natl. Acad. Sci. USA 91:2975-2979.

3.Parker, J.D., P.S. Rabinovitch and G.C. Burmer. 1991. Targeted gene walking polymerase chain reaction. Nucleic Acids Res. 19:3055-3060.

4.Sambrook, J., E.F. Fritsch and T. Maniatis. 1989. Molecular Cloning: A Laboratory Manual. Cold Spring Harbor Laboratory Press, Cold Spring Harbor, NY.

5.Triglia, T., M.G. Peterson and D.J. Kemp. 1988. A procedure for in vitro amplification of DNA segments that lie outside the boundaries of known sequences. Nucleic Acids Res. 16:8186.

Address correspondence to Russell C. Johnson, Department of Microbiology, University of Minnesota Medical School, Mayo Memorial Building Room 1020, 420 Delaware St., S.E. Minneapolis, MN 55455, USA. Internet: johnson@lenti.med.umn.edu

Received 28 July 1995; accepted 18 January 1996.

Gabriel A. Trueba and Russell C. Johnson

University of Minnesota Medical School

Minneapolis, MN, USA

Improved PCR Amplification of Multiple Specific Alleles (PAMSA) Using Internally Mismatched Primers

\section{BioTechniques 21:20-26 (July 1996)}

The polymerase chain reaction (PCR) can detect DNA single-base change mutations or polymorphisms using an allele-specific primer designed 
to match only one of the possible allele sequences at its 3'-terminal nucleotide. This method (1) is known by various names: amplification refractory mutation system (ARMS) (6), allele-specific PCR (ASPCR) (9) and PCR amplification of specific alleles (PASA) $(1,7,8)$. Dutton and Sommer (3) describe a particularly useful variation, PCR amplification of multiple specific alleles (PAMSA), which involves the use of two (or more) allele-specific primers in the same PCR, so that either or both alleles in a sample can be amplified. As noted previously $(1,3)$, PAMSA has three advantages over earlier methods: $(i)$ primer specificity is maintained even with high template concentrations, (ii) homozygotes can be distinguished from heterozygotes in a single PCR (iii) and an internal control for successful amplification is inherent in the PAMSA process. However, the use of PAMSA has not been widely reported, perhaps because the conditions for a successful test system can be time-consuming to develop. Another previously mentioned (6), but rarely used, modification of PASA involves the use of internal primer mismatches to confer improved allele specificity. An additional mismatch (to all alleles) internal to the allele-specific primer can improve specificity and also allow for the amplification of shorter PCR products than can be used in the traditional PASA process $(1,8)$. This report substantiates the advantages of internally mismatched primers, which allow for the amplification of shorter DNA products, reduce background amplification and require less careful adjustment of PCR conditions in both PASA and PAMSA.

We have used PASA to map singlebase change polymorphisms in a reference chicken population (2) arising from either the J (Jungle Fowl) or W (White Leghorn) progenitor genome. The polymorphisms in question were originally identified by random-amplified polymorphic DNA (RAPD)-type PCR techniques $(2,4)$, and the regions encoding some of these loci have since been cloned and sequenced in both alleles (unpublished). To use preexisting primers in addition to new allele-specific primers for further PASA typing, it was necessary to amplify products
Table 1. Primer Sequences

\begin{tabular}{|c|c|c|c|c|}
\hline Locus & Primers & Sequence ${ }^{a}$ & & $\mathrm{~T}_{\mathrm{m}}{ }^{\mathrm{b}}{ }^{\circ} \mathrm{C}$ \\
\hline \multirow[t]{7}{*}{ MSU33 } & Genomicc & GTGGTGTAGTCTTTCAGGTCAGTGA/G & $5^{\prime}$ & \\
\hline & $33 W C 2-1$ & TTTTTCATCAGAAAGTCCAGTCICT & $3^{\prime}$ & $60 / 70^{d}$ \\
\hline & 33WC2-2 & TTTTCGATCAGAAAGTCCAGTCICT & $3^{\prime}$ & $56 / 72^{d}$ \\
\hline & 33JC2 & CATCAGAAAGTCCAGTCCূCC & $3^{\prime}$ & 62 \\
\hline & 33JC1 & CATCAGAAAGTCCAGTCATC & $3^{\prime}$ & 58 \\
\hline & 33JC0 & CATCAGAAAGTCCAGTCACC & $3^{\prime}$ & 60 \\
\hline & $33 \mathrm{com}^{\mathrm{e}}$ & AGACACATTGCTGACTCATGTTC & $3^{\prime}$ & 66 \\
\hline \multirow[t]{4}{*}{ MSU34 } & Genomicc & 3' AACAAA-GAACCTCTGTCAAAACTGAC/T & $5^{\prime}$ & \\
\hline & $34 \mathrm{WC2}$ & 5' TTGTTT-CTTGGAGACAGTTTTGAÄTG & $3^{\prime}$ & 70 \\
\hline & 34JC2 & TTTGCTTGGAGACAGTTTTGAGTA & $3^{\prime}$ & 66 \\
\hline & 34 come & GCTAGTGATTTTGATAGAAGCCT & $3^{\prime}$ & 64 \\
\hline \multicolumn{5}{|c|}{$\begin{array}{l}\text { aUnderlined bases denote internal primer sequence mismatches to both } \\
\text { alleles. }\end{array}$} \\
\hline \multicolumn{5}{|c|}{$\begin{array}{l}{ }^{b} T_{m} \text { as per Miyada and Wallace (5). Mismatches not used in estimating } T_{m} \text {. } \\
{ }^{\prime} \text { Genomic sequence shown } 3^{\prime} \text { to } 5^{\prime} \text { with polymorphism shown as W/J allele } \\
\text { sequence. }\end{array}$} \\
\hline \multicolumn{5}{|c|}{$\begin{array}{l}\mathrm{d} \mathrm{T}_{\mathrm{m}} \text { of full primer length including the } 5-6 \text { additional mismatched bases at } \\
\text { the } 5^{\prime} \text { end. }\end{array}$} \\
\hline \multicolumn{5}{|c|}{ eCommon primer of the PASA or PAMSA reaction. } \\
\hline
\end{tabular}

considerably smaller than the recommended minimum $(1,8)$ of 200 bp. Under these conditions, traditional PASA primers may not provide adequate allele-specific amplification. Figure 1 shows that even at high annealing tem- perature, the PASA primer set without an internal mismatch ( $\mathrm{C} 0$ primer) gives a false-positive signal (W lanes). Primers are designated by locus number, followed by allele-specificity ( $\mathrm{J}$ or $\mathrm{W}$ ), followed by a designation regarding

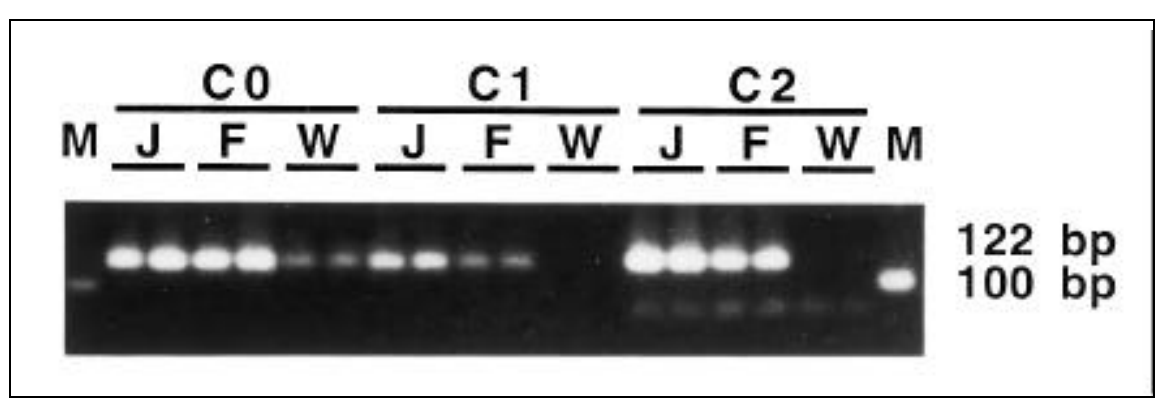

Figure 1. PASA amplification products at the MSU33 locus obtained with primer sets with different internal mismatched nucleotides. Primers (Table 1) include $33 \mathrm{com}$ as the common primer and $33 \mathrm{JC} 0,33 \mathrm{JC} 1$ or 33JC2 (lanes designated $\mathrm{C} 0, \mathrm{C} 1$ or $\mathrm{C} 2$, respectively). The products of two independent reactions are loaded side by side in each case. Template DNAs are indicated by $\mathrm{J}$ (Jungle Fowl allele homozygote), $\mathrm{F}$ ( $\mathrm{F}_{1}$ heterozygote) and $\mathrm{W}$ (White Leghorn homozygote). $\mathrm{M}$ indicates the marker lane. The $\mathrm{C} 2$ primer gives the most intense positive signal $(\mathrm{J}$ and $\mathrm{F})$ with no spurious amplification in W. PASA was performed in $50 \mathrm{mM} \mathrm{KCl}, 10 \mathrm{mM}$ Tris- $\mathrm{HCl}(\mathrm{pH} 9.0), 0.1 \%$ Triton ${ }^{\circledR} \mathrm{X}-100,1.5 \mathrm{mM} \mathrm{MgCl}, 0.1 \mathrm{mM}$ dNTPs, $0.1 \mu \mathrm{M}$ of each primer with $0.25 \mathrm{U}$ Taq DNA polymerase (Promega, Madison, WI, USA) and 15 ng of chicken genomic DNA (2) per $25 \mu \mathrm{L}$ reaction. Model PTC-100 ${ }^{\mathrm{TM}}$ PCR machines (MJ Research, Watertown, MA, USA) were used throughout. The PCR program was $94^{\circ} \mathrm{C}$ for $2.5 \mathrm{~min} ; 35$ cycles of $30 \mathrm{~s}$ at $94^{\circ} \mathrm{C}, 1.0 \mathrm{~min}$ at $60^{\circ} \mathrm{C}$ and $1.0 \mathrm{~min}$ at $72^{\circ} \mathrm{C}$; followed by $72^{\circ} \mathrm{C}$ for $5 \mathrm{~min}$ and storage at $4^{\circ} \mathrm{C}$. PCR aliquots $(20 \mu \mathrm{L})$ were loaded directly onto $3 \%$ agarose gels in $1 \times$ TAE $(40 \mathrm{mM}$ Tris-acetate, $2 \mathrm{mM}$ EDTA, $\mathrm{pH} 8.0$ ) with $0.15 \mu \mathrm{g} / \mathrm{mL}$ ethidium bromide in gel and buffer. Gels were run at $80 \mathrm{~V}$ for $3-4 \mathrm{~h}$. Molecular weight standards (250 ng of a 100-bp ladder) were from Life Technologies, Gaithersburg, MD, USA. 
internal mismatches near the $3^{\prime}$ end, if any, (Table 1). At a lower annealing temperature $\left(45^{\circ} \mathrm{C}\right)$, amplification with the $\mathrm{C} 0$ primer is indistinguishable on both polymorphic templates (results not shown) and therefore useless for genotyping. By designing the allelespecific primers with an additional mismatch, improved allele-specificity was observed and successful PASA reactions were much less dependent on the choice of PCR conditions. As shown in Figure 1 for the MSU33 locus, the optimal allele-specific primer $(\mathrm{C} 2)$ has a mismatch 2 bases in from its $3^{\prime}$ allelespecific base, that is, 3 bases in from its $3^{\prime}$ end (compare $\mathrm{C} 0$, no added mismatch, $\mathrm{C} 1$ with an added mismatch adjacent to the $3^{\prime}$ allele-specific base and C2). This was also true for MSU34 (not shown), and a similar observation was made by Newton et al. (6) for the $\mathrm{Z}$ allele of the human $\alpha 1$-antitrypsin gene. Using PASA with mismatched primers, we have typed 5 loci for which the products were between 91 and $163 \mathrm{bp}$ (data not shown). The mismatch at 3 bases in from the 3' end seems to be optimal for a variety of loci.

The fact that shorter products than had previously been described can easily be typed by PASA when using mismatched primers suggested that this approach might be especially applicable to PAMSA. PAMSA involves the simultaneous use of primers complementary to both alleles in question and distinguishes between the two alleles by making one allele-specific primer (and, therefore, product) longer than the other. We designed both PAMSA allelespecific primers to include a mismatch 3 bases from their $3^{\prime}$ termini. To minimize complementarity between one allele-specific primer and the product of the other, different mismatched bases were incorporated at the internal site in the two primers (Table 1). In addition to increasing the allele-specificity of the two PAMSA primers, the internal sequence differences between the primers minimized cross-amplification in later PCR cycles. This allowed us to increase the annealing temperature at the fifth PCR cycle to provide a larger yield of product without compromising allele specificity.

Dutton and Sommer (3) used one allele-specific primer that was $31 \mathrm{nu}$ - cleotides longer than the other in the original description of the PAMSA technique. This size difference can be expensive to synthesize and could also be cumbersome in automated, multiplex assays. Since PAMSA with mismatched primers may facilitate typing of shorter products, we have tested assays in which one allele-specific primer is 5 or even only 2 nucleotides longer than the other. In both cases, the different alleles were clearly resolved on acrylamide gels. In the case of MSU33, the $\mathrm{J}$ allele-specific primer generates a 122 -bp product and the $\mathrm{W}$ allele-specific primer produces one of $127 \mathrm{bp}$ (Figure 2A), while in the case of MSU34, the $\mathbf{J}$ allele-specific primer generates a 91-bp product and the $\mathrm{W}$ allele-specific primer generates one of $93 \mathrm{bp}$ (Figure 2B). In all cases, heterozygotes (lanes F and B in Figure 2A and lanes F, B5 and B6 in Figure 2B) can be clearly identified. Note that in the case of the MSU34 typing, the additional two base pairs at the $5^{\prime}$ end of the longer PAMSA allele-specific primer can be fully complementary to genomic DNA (as opposed to random extensions used previously) without significantly skewing its melting temperature $\left(\mathrm{T}_{\mathrm{m}}\right)$ and competitive priming ability relative to the shorter allele-specific primer.

We originally used primer 33WC2-1 (Table 1) for PAMSA typing MSU33. This primer generated an additional diffuse band between the expected 122$\mathrm{bp}(\mathrm{J})$ and $127-\mathrm{bp}(\mathrm{W})$ products (Figure $2 \mathrm{~A}$, primer set 1 , lane J). While genotyping could be accurately assessed in this case, the diffuse band could impair the ability to use automated analysis. Dutton and Sommer (3) observed a similar problem, which may be due to
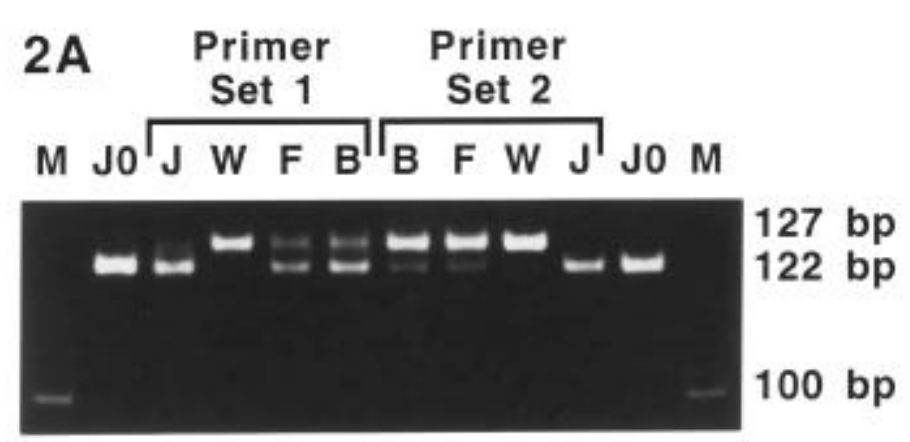

2B

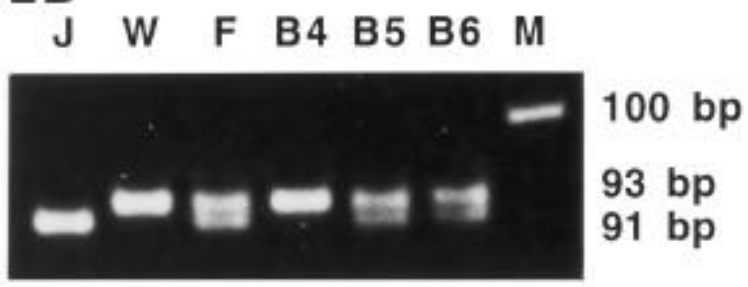

Figure 2. (A) PAMSA amplification products at the MSU33 locus. Primer set 1 consists of 33WC2-1 $(0.15 \mu \mathrm{M})$ and $33 \mathrm{JC} 2(0.05 \mu \mathrm{M})$, along with $33 \mathrm{com}(0.1 \mu \mathrm{M})$ as the common primer (Table 1$)$. Primer set 2 contains $33 \mathrm{WC} 2-2$ in place of 33WC2-1 at the same concentration. Template DNAs are indicated by $\mathbf{J}$ (homozygote for $\mathrm{J}$ allele), $\mathrm{W}$ (homozygote for $\mathrm{W}$ allele), $\mathrm{F}\left(\mathrm{F}_{1}\right.$ heterozygote) and $\mathrm{B}$ (backcross, $\mathrm{F}_{1} \times \mathrm{WL}$, heterozygote), respectively. J0 is a control reaction with homozygous J template and only the $33 \mathrm{JC} 2$ and $33 \mathrm{com}$ primers. $\mathrm{M}$ is the marker lane; only the $100-\mathrm{bp}$ band is visible. Sizes in bp of bands are provided to the right. (B) PAMSA amplification products at the MSU34 locus. Primers (Table 1) used are 34WC2 $(0.15 \mu \mathrm{M})$ and $34 \mathrm{JC} 2(0.05 \mu \mathrm{M})$, along with $34 \mathrm{com}(0.1 \mu \mathrm{M})$. Lane designations are as in (Panel A). B4, B5 and B6 are three different backcross progeny that demonstrate a W allele homozygote and two heterozygotes, respectively. PAMSA was performed in the reaction buffer described in the legend to Figure 1 with $1.0 \mathrm{U}$ of Taq DNA polymerase and $60 \mathrm{ng}$ of template DNA per 50- $\mu \mathrm{L}$ reaction. The PCR program was $94^{\circ} \mathrm{C}$ for $2.5 \mathrm{~min} ; 4$ cycles of $30 \mathrm{~s}$ at $94^{\circ} \mathrm{C}, 30 \mathrm{~s}$ at $55^{\circ} \mathrm{C}$ and $1.0 \mathrm{~min}$ at $72^{\circ} \mathrm{C} ; 31$ cycles of $30 \mathrm{~s}$ at $94^{\circ} \mathrm{C}, 1.0 \mathrm{~min}$ at $60^{\circ} \mathrm{C}$ and $1.0 \mathrm{~min}$ at $72^{\circ} \mathrm{C}$; followed by $72^{\circ} \mathrm{C}$ for $5 \mathrm{~min}$ and storage at $4^{\circ} \mathrm{C}$. PCR aliquots $(20 \mu \mathrm{L})$ were mixed with $10 \mu \mathrm{L}$ of loading dye $(80 \%$ glycerol, $0.25 \%$ bromophenol blue, and $0.1 \times \mathrm{TBE}$ [ $1 \times$ TBE is $90 \mathrm{mM}$ Tris-borate and $2.0 \mathrm{mM}$ EDTA]) and run on $6 \%$ acrylamide (20:1 acrylamide to bisacrylamide) gels $(18.5 \times 30 \times 0.15 \mathrm{~cm})$ with $1.5 \times \mathrm{TBE}$ in the gel and $1 \times \mathrm{TBE}$ in the buffer. Gels were run at $200 \mathrm{~V}$ until the bromophenol blue ran $29 \mathrm{~cm}$, stained with ethidium bromide at $0.3 \mu \mathrm{g} / \mathrm{mL}$ for 20 min and destained for $20 \mathrm{~min}$ in water. 


\section{Benchmarks}

"megapriming" (1), in which heteroduplex formation between PCR product strands and primers tend to convert the smaller product to the larger one. Megapriming in the 33WC2-1 reaction may have been enhanced by the fact that the $5^{\prime}$ extension of this primer consists of five extra dT residues, which would be complementary to any added $3^{\prime} \mathrm{dA}$ nucleotides that could be incorporated by the terminal transferase activity of Taq DNA polymerase. Consistent with this interpretation, primer 33WC2-2 (Table 1), in which a CG sequence is substituted for the TC sequence at the junction between matched and extension nucleotides in $33 \mathrm{WC} 2-1$, generates no intermediate band. Furthermore, no artifactual band is observed for the MSU34 typing, in which the smaller allele-specific primer has a single nucleotide difference near its $5^{\prime}$ end with regard to the longer primer (and genomic DNA). We conclude that short $5^{\prime}$ extensions of the longer allele-specific primer are suitable for PAMSA, but should not be solely dT residues. It may also be useful to include an additional sequence difference near the $5^{\prime}$ end of allele-specific PAMSA primers, in addition to the one three nucleotides from the $3^{\prime}$ end.

As noted previously $(1,3)$, the PAMSA technique can be very sensitive to the molar ratio of the allele-specific primers. In the case of MSU33 (using 33WC2-1) and MSU34, the smaller product tended to outcompete the larger one at equimolar primer concentrations. In our experience, the most effective allele-specific primer should be maintained at a concentration of at least $0.05 \mu \mathrm{M}$, while the concentration of the other allele-specific primer can be optimized. In the case of MSU33 (using 33WC2-1) and MSU34, a 3:1 ratio (i.e., $0.15 \mu \mathrm{M}: 0.05 \mu \mathrm{M}$ ) was near optimal. As seen in Figure 2A, 3:1 is not optimal for typing MSU33 with 33WC2-2 (further tests indicate a 2:1 ratio is best for primer set 2). However, while some empirical adjustments of primer concentrations may be required, our experience suggests that optimal primer ratios are more nearly equimolar when internally mismatched primers are used in combination with short $5^{\prime}$ extensions and that, in general, PAMSA is effective at a wider range of PCR conditions when internally mismatched primers are used. Mismatched primer PAMSA allows for point mutation/polymorphism detection in shorter amplified products, with smaller differences in product sizes, and easier adjustment of PCR conditions than traditional PAMSA or other PASA-type techniques. The analysis of the MSU33 locus has been repeated using a fluorescently labeled 33com common primer and an Applied Biosystems Model 373 automated DNA sequencer (Perkin-Elmer/ Applied Biosystems Division, Foster City, CA, USA) with results identical to those shown in Figure 2A. As expected, PAMSA products differing in length by only a few bp are very well-resolved in the automated analysis process. This suggests that design of PAMSA (or PASA) primers with internal mismatches can facilitate typing of single base change polymorphisms by automated, as well as manual, techniques.

\section{REFERENCES}

1.Bottema, C.D.K., G. Sarkar, J.D. Cassady, S. Ii, C.M. Dutton and S.S. Sommer. 1993. Polymerase chain reaction amplification of specific alleles: a general method of detection of mutations, polymorphisms, and haplotypes. Methods Enzymol. 218:388-402.

2.Crittenden, L.B., L. Provencher, L. Santangelo, I. Levin, H. Abplanalp, R.W. Briles, W.E. Briles and J. B. Dodgson. 1993. Characterization of a red jungle fowl by white leghorn backcross reference population for molecular mapping of the chicken genome. Poult. Sci. 72:334-348.

3.Dutton, C. and S.S. Sommer. 1991. Simultaneous detection of multiple single-base alleles at a polymorphic site. BioTechniques 11:700-702.

4.Levin, I., L.B. Crittenden and J.B. Dodgson. 1994. Polymorphic DNA mapping using avian CR1 element-derived PCR primers. J. Hered. 85:73-78.

5.Miyada, C.G. and R.B. Wallace. 1987. Oligonucleotide hybridization techniques. Methods Enzymol. 154:94-107.

6.Newton, C.R., A. Graham, L.E. Heptinstall, S.J. Powell, C. Summers, N. Kalsheker, J.C. Smith and A.F. Markham. 1989. Analysis of any point mutation in DNA: the amplification refractory mutation system (ARMS). Nucleic Acids Res. 17:2503-2516.

7 Sarkar, G., J. Cassady, C.D.K. Bottema and S.S. Sommer. 1990. Characterization of polymerase chain reaction amplification of specific alleles. Anal. Biochem. 186:64-68.

8.Sommer, S.S., A.R. Groszbach and C.D.K. Bottema. 1992. PCR amplification of specific alleles (PASA) is a general method for rapidly detecting known single-base changes. BioTechniques 12:82-87.

9.Wu, D.Y., L. Ugozzoli, B.K. Pal and R.B.
Wallace. 1989. Allele-specific enzymatic amplification of $\beta$-globin genomic DNA for diagnosis of sickle cell anemia. Proc. Natl. Acad. Sci. USA 86:2757-2760.

This research was supported by USDA NRI-CGP Grant 93-37205-9344. We thank Barbara Okimoto for technical assistance and Hans Cheng of the USDA-ARS Avian Disease and Oncology Laboratory, East Lansing, MI, USA for access to automated sequencing equipment. Address correspondence to Jerry Dodgson, Department of Microbiology, Giltner Hall, Michigan State University, East Lansing, MI 48824, USA. Internet: 22314jbd@msu.edu

Received 20 October 1995; accepted 16 January 1996.

Ronald Okimoto and Jerry B.
Dodgson
Michigan State University
East Lansing, MI, USA

